\title{
PERFORMANCE, CARCASS AND BIO-ECONOMICS OF BROILER CHICKENS FED AIDAN (TETRAPLEURA TETRAPTERA) AND OR TURMERIC (CURCUMA LONGA) AS DIETARY ADDITIVES
}

\author{
${ }^{* 1}$ Ingweye, J.N.; ${ }^{2}$ Kalio, G.A. and ${ }^{1}$ Thomas E.S. \\ ${ }^{1}$ Department of Animal Science, Faculty of Agriculture, University of Port Harcourt, \\ PMB 5323, Choba, Port Harcourt, Nigeria. \\ ${ }^{2}$ Department of Agriculture, Faculty of Vocational and Technical Education, \\ Ignatius Ajuru University of Education, Port Harcourt, Nigeria \\ *Corresponding author
}

DOI: https://doi.org/10.51193/IJAER.2021.7106

\begin{abstract}
Effect of consuming aidan and turmeric as feed additives on the performance, carcass and bioeconomics of broiler birds was evaluated in a 56-day study. One hundred and eighty birds were shared into six groups of thirty birds per group. Chickens were allocated to six dietary treatments tagged T1, T2, T3, T4, T5 and T6. Each treatment was shared into three replicates of ten birds each. T1 or control diet had no aidan nor turmeric. T2, T3, T4, T5 and T6 diets had $0.5 \%$ aidan, $1.0 \%$ aidan, $0.5 \%$ aidan $+0.5 \%$ turmeric, $1.0 \%$ turmeric and $0.5 \%$ turmeric, respectively. The starter diets contained $23.0 \%$ crude protein and $2,800.0 \mathrm{kcal}(\mathrm{ME}) / \mathrm{kg}$ energy while finisher diets contained $20.0 \%$ crude protein and 3,200.0 kcal (ME)/kg energy. Feed and water were offered ad libitum. Completely Randomized Design format, one-way analysis of variance was used for the study. T4 diet improved $(\mathrm{p}<0.05)$ final live weight; weight gain; slaughter, plucked and dressed weights; and reduced $(\mathrm{p}<0.05)$ feed intake and feed conversion ratio. Furthermore, T4 diet improved $(\mathrm{p}<0.05)$ carcass breast. Adding any of the spices to diets suppressed $(\mathrm{p}<0.05)$ abdominal fat deposition. T4 diet is recommended for optimal performance, carcass and bioeconomics of birds.
\end{abstract}

Keywords: Phyto-additives, spices, gross margin, weight gain, poultry

\section{INTRODUCTION}

The production goal of most broiler chicken farmers is to optimize feed intake, growth rate, weight gain, health and product quality of their birds (TPS, 2019; Karaskova et al., 2015). To achieve those goals, farmers across the world add growth-promoting antibiotics to feed and 
International Journal of Agriculture and Environmental Research

ISSN: 2455-6939

Volume: 07, Issue: 01 "January-February 2021"

drinking water of their poultry (Puvaca et al., 2013). However, research on the impact of these antibiotics on the birds, their products, consumers and environment indicates that the abuse in the use of antibiotics is a major cause of antibiotic resistance in humans and birds, as well as pollution of the environment (EC, 2005). This led to the ban on the use of antibiotics in producing chickens, whose products are meant for human consumption, first by the European Union in 2006, and subsequently by other countries (USGAO, 2011; EC, 2005; Puvaca et al., 2013). This ban created opportunities for research that examines natural products, for their potential to improve animal health, performance, and product quality, without polluting the environment, or causing antimicrobial resistance in man and livestock (Ingweye et al., 2019). Several plant products, normally consumed as spices by man, have been evaluated and used individually or in combination as non-antibiotic growth-promoters with positive results (Karaskova et al., 2015; Sunilet al., 2009). Examples of those phyto-additives commonly used in poultry nutrition include ginger, garlic and turmeric (Khan, et al., 2012; Karangiya, et al., 2016).However, the local and global demand for those conventional spices for use in herbal teas, ethnic cuisines, cosmetics, pharmaceuticals, functional foods and nutrition products is huge (Mani and Kabiraj, 2019). This huge demand has induced increases in the prices of those wellknown spices (Mani and Kabiraj, 2019; Jansen, 2020) and consequently, cost of feeds they are used to produce, beyond what smallholder farmers can afford. In addition, the continuing push for their use in livestock feed when direct human use has not been adequately satisfied presents a moral and economic burden. This competition between man and farm animals for conventional spices has instigated a search for locally available, cheaper, yet lesser-known Nigerian spices with potential to reduce or completely replace conventional non-antibiotic growth-promoters in animal feed (Ingweye et al., 2019).Ultimately, it is hoped that their reduction or replacement could help release those conventional spices for preferred use by man, to reduce the cost of feed produced with those lesser-known spices and promote growth and health of the birds. One of those lesser-known local Nigerian spices with the potential to replace the conventional spices in livestock diets is aidan.

Aidanis a lowland forest tree spice indigenous to Nigeria and known as Uyayak (Ibibio and Efik), Dawo (Hausa), Oshosho (Ibo) and Aridan (Yoruba). According to Aladesanmi (2007), the tree is single-stemmed, robust and grows to about 30 meters high with round branchlets. The fruit/pod is 12 to $25 \mathrm{~cm}$ by $3 \frac{1}{2}$ to $6 \frac{1}{2} \mathrm{~cm}$, dark-brown, four-winged pod, fleshy pulped, having small black-brown seeds and pungent odour. The pod has been used as food spice, for perfume, as molluscicide and in treating cardiovascular, neuromuscular, hypotensive, trypanocidal, antiulcerative, anthelminthic, hypoglycaemic, and microbial diseases and in managing convulsion, inflammation, rheumatism, and birth control (Achi, 2006; Aladesanmi, 2007). Aidan pod powder contains $5 \%$ moisture, $14 \%$ ash, $11 \%$ crude protein, $8 \%$ fat, $62 \%$ crude fibre and active ingredients such assaponin, glycosides, tannins, and oleanolic acid, aglycone (Achi, 2006; 
International Journal of Agriculture and Environmental Research

ISSN: 2455-6939

Volume: 07, Issue: 01 "January-February 2021"

Aladesanmi, 2007). There is a possibility of combining aidan and turmeric powders in poultry diet in order to reap the benefit of both.

Turmeric (Curcuma longa), belongs to the family Zingiberaceae and naturally grows in southeast Asia, especially India. It is a leafy permanent crop that grows upright to $1 \frac{1 / 2}{2}$ meters tall (Bejar, 2018). Turmeric flourishes in the wet tropics at $20^{\circ} \mathrm{C}-30^{\circ} \mathrm{C}$ temperature and sandy-loam or clay-loam soil that is light black and friable (Yadav and Tarun, 2017). The most vital part of the crop is the rhizome, which is usually utilized as food spice and herbal remedy, while curcumin is its most bioactive ingredient (Nasriet al., 2014). Turmeric rhizome has 0.34, 0.26, $0.43,2.86$ and $0.93 \mathrm{~g}$ of crude protein, ash, ether extractives, nitrogen free extractives and crude fibre, respectively. Also, it contains 12.4, 18.1, 2.8, 0.3, 13.0, 2.6, 170, 1.7 and $3.3 \mathrm{mg}$ of calcium, phosphorus, iron, zinc, magnesium, potassium, sodium, vitamin $\mathrm{C}$ and choline, respectively and $2.6 \mathrm{mcg}$ offolate (Vyas, 2015; Yadav and Tarun, 2017). It has been reported to exhibit anti-inflammatory, antioxidant, anti-coagulant, anti-diabetic, anti-microbial, anti-ulcer activities (Bejar, 2018; Yadav and Tarun, 2017; Nasri et al., 2014). Turmeric powder can be tolerated at high doses when administered as herbal or nutritional remedy but abusing its use could result in significant side-effects such as increasing bleeding and gall bladder problems, activating uterine contraction during pregnancy, lessening iron absorption, testosterone levels and sperm motility (Yadav and Tarun, 2017).

Turmeric powder either alone or in mixture with black pepper, garlic, thyme and coriander has been reportedly used as feed additive for poultry (Fallah and Mirzae, 2016). Studies have shown the impact of aidan pod extract and powder, singly or in combination with other phyto-additives, such as rosemary and thyme, oncarcass characteristics, organ weights, growth performances and serum biochemistry of broiler chickens (Nweze et al., 2011; Adeyemo, 2014; Olorunleke et al., 2016; Kana et al., 2017). Similarly, Ingweye et al (2019) assessed the effect of aidan pod powder co-administered with turmeric as dietary feed additives on blood chemistry, proximate composition and organoleptic indices of broiler chicken meat. But, no study has examined the effect of co-including aidan and turmeric powders on the performance, carcass, organ and economics of production of broiler chickens. Therefore, this study was aimed at testing the effect of combining aidan and turmeric powders as feed additives on broiler chicken performance, carcass and organ indices as well as economics of production. Results will deepen the understanding on the interactive effect on the use of aidan with turmeric as broiler chicken feed additives.

\section{MATERIALS AND METHODS}

\subsection{Research site location}


The experiment was carried out in the Teaching and Research Farm, University of Port Harcourt, Choba, Rivers State. Geographical indices of the site include: latitude $4.89437^{\circ} \mathrm{N}$, longitude $6.91053^{\circ} \mathrm{E}, 16 \mathrm{~m}$ above sea level and $28^{\circ} \mathrm{C}$ average annual temperature (Oyegun and Adeyemo, 1999).

\subsection{Research animals, feed materials and diets}

The Cobb-500 strain day-old chicks were used for the study. They were obtained from a commercial hatchery; Zartech Ltd., Oyo State, Nigeria.

The feed ingredients were purchased from feed ingredient stores in Obo market, EtimEkpo Local Government Area, Akwalbom State. Aidan pods and turmeric rhizomes were chopped into small pieces and sun-dried before milling to powder. The chicken starter diets were compounded to provide23.0\% crude protein and 2,800.0 kcal (ME)/kg energy where as broiler chicken finisher diets were compounded to yield20.0 \% crude protein and 3,200.0 kcal (ME)/kg energy. The composition of the diets is shown in Table 1.

Table 1: Composition of broiler chicken experimental diets containing aidan and tumeric

\begin{tabular}{|c|c|c|c|c|c|c|c|c|c|c|c|c|}
\hline \multirow[b]{3}{*}{$\begin{array}{l}\text { Ingredient } \\
\text { S }\end{array}$} & \multicolumn{12}{|c|}{ Treatment groups } \\
\hline & \multicolumn{6}{|c|}{ Broiler chicken starter diets } & \multicolumn{6}{|c|}{ Broiler chicken finisher diets } \\
\hline & T1 & T2 & T3 & T4 & T5 & T6 & T1 & T2 & T3 & T4 & T5 & T6 \\
\hline Aidan & - & 0.5 & 1.0 & 0.5 & - & - & - & 0.5 & 1.0 & 0.5 & - & - \\
\hline Turmeric & - & - & - & 0.5 & 1.0 & 0.5 & - & - & - & 0.5 & 1.0 & 0.5 \\
\hline Maize & 48.0 & 47.5 & 47.0 & 47.0 & 47.0 & 47.5 & 52.0 & 51.5 & 51.0 & 51.0 & 51.0 & 51.5 \\
\hline $\begin{array}{l}\text { Soybean } \\
\text { meal }\end{array}$ & 36.0 & 36.0 & 36.0 & 36.0 & 36.0 & 36.0 & 28.0 & 28.0 & 28.0 & 28.0 & 28.0 & 28.0 \\
\hline Fish meal & 5.0 & 5.0 & 5.0 & 5.0 & 5.0 & 5.0 & 4.00 & 4.0 & 4.0 & 4.0 & 4.0 & 4.0 \\
\hline Wheat offal & 6.0 & 6.0 & 6.0 & 6.0 & 6.0 & 6.0 & 10.0 & 10.0 & 10.0 & 10.0 & 10.0 & 10.0 \\
\hline Bone meal & 2.5 & 2.5 & 2.5 & 2.5 & 2.5 & 2.5 & 3.0 & 3.0 & 3.0 & 3.0 & 3.0 & 3.0 \\
\hline Salt & 0.5 & 0.5 & 0.5 & 0.5 & 0.5 & 0.5 & 0.5 & 0.5 & 0.5 & 0.5 & 0.5 & 0.5 \\
\hline Methionine & 0.25 & 0.25 & 0.25 & 0.25 & 0.25 & 0.25 & 0.25 & 0.25 & 0.25 & 0.25 & 0.25 & 0.25 \\
\hline Lysine & 0.25 & 0.25 & 0.25 & 0.25 & 0.25 & 0.25 & 0.25 & 0.25 & 0.25 & 0.25 & 0.25 & 0.25 \\
\hline $\begin{array}{l}\text { Vitamin } \\
\text { premix }\end{array}$ & 0.5 & 0.5 & 0.50 & 0.5 & 0.5 & 0.5 & 0.5 & 0.5 & 0.5 & 0.5 & 0.5 & 0.5 \\
\hline Palm oil & 1.0 & 1.0 & 1.00 & 1.0 & 1.0 & 1.0 & 1.5 & 1.5 & 1.5 & 1.5 & 1.5 & 1.5 \\
\hline
\end{tabular}


International Journal of Agriculture and Environmental Research

ISSN: 2455-6939

Volume: 07, Issue: 01 "January-February 2021"

\begin{tabular}{|c|c|c|c|c|c|c|c|c|c|c|c|c|}
\hline Total & 100.0 & 100.0 & 100.0 & 100.0 & 100.0 & 100.0 & 100. & 100.0 & 100.0 & 100.0 & 100.0 & 100.0 \\
\hline $\begin{array}{l}\text { Crude protein } \\
\text { (\%) }\end{array}$ & 23.1 & 23.0 & 23.0 & 23.0 & 23.0 & 23.0 & 20.9 & 21.0 & 21.0 & 21.0 & 21.0 & 21.0 \\
\hline \multicolumn{13}{|l|}{$\begin{array}{l}\text { Energy (ME } \\
\mathrm{Kcal} / \mathrm{kg} \text { ) }\end{array}$} \\
\hline & $\begin{array}{l}2,828 . \\
0\end{array}$ & $\begin{array}{l}2,811 . \\
0\end{array}$ & $\begin{array}{l}2,794 . \\
0\end{array}$ & $2,794.0$ & $2,794.0$ & $2,811.0$ & $3,215.0$ & $3,210.0$ & $3,270.0$ & $3,200.0$ & $3,210.0$ & $3,195.0$ \\
\hline
\end{tabular}

\subsection{Feeding and other management procedures}

The experimental birds were managed in an open-sided poultry house and deep litter system. The poultry house, drinkers, feeders, and other equipment were washed and disinfected two weeks (disease break period)before arrival of the birds. Wood shavings were used as litter material and spread on the floor to $5.0 \mathrm{~cm}$ depth. The wood shavings were changed as often as needed to keep the pens clean, dry and free from infection. On arrival, the birds were administered glucose and multivitamins in water to relief stress. Adequate heat was also provided in the poultry house using kerosene lanterns and stoves. Initial temperature for the first week was at $35^{\circ} \mathrm{C}$ which was reduced by $2.8^{\circ} \mathrm{C}$ each week till end of 3-week brooding. Experimental diets and clean drinking water were given to the chickens (ad libitum) twice daily at 7.00 hours GMT (+1) and 16.00 hours GMT (+1). The birds were vaccinated against Newcastle and Gumboro diseases as well prophylactically treated against avian Coccidiosis according to methods described by Ingweye $e t$ al. (2008).Other poultry management and routine biosecurity procedures were also carried out.

\subsection{Experimental design}

One hundred and eighty (180) day-old broiler chicks were used for the56-daystudy. The birds were divided into six groups of thirty (30) birds per group. The groups were further shared into three replicates of ten (10) birds each. Average initial weights of the birds per group were balanced across the groups to minimize bias. The groups of birds were randomly allotted to six dietary treatments (T1, T2, T3, T4, T5, and T6). Treatment T1 was the control. It contained neither aidan nor turmeric. Treatments T2, T3, T4, T5 and T6 diets contained $0.5 \%$ aidan, $1.0 \%$ aidan, $0.5 \%$ aidan plus $0.5 \%$ turmeric, $1.0 \%$ turmeric and $0.5 \%$ turmeric, respectively. The research was arranged in a Completely Randomized Design (CRD) format, one-way analysis of variance.

\subsection{Data collection procedure}

The parameters assessed were feed intake, weight gain, feed conversion ratio (FCR), carcass and organ characteristics and economics of production. Feed offered and leftover were recorded once a day while live weights were recorded once a week. Feed intake was calculated by subtracting the quantity of feed left over from feed offered after 24 hours. Weight gain was calculated on 
International Journal of Agriculture and Environmental Research

ISSN: 2455-6939

Volume: 07, Issue: 01 "January-February 2021"

weekly basis by subtracting the present weight from the previous week weight. Feed conversion ratio was calculated by dividing the feed intake by weight gain.

Economics of production (gross margin) was calculated using cost of ingredients (market prices of feed ingredients per kilogramme when they were bought), feed intake and weight gain to compute the cost of feed per kilogram diet, cost of feed consumed per animal and cost of weight gain per animal.

On the $56^{\text {th }}$ day of the experiment, when the final body weight of the birds would have been taken, a bird per replicate or three per treatment whose individual weights were similar to the treatment group's average were picked for assessment of carcass and organ characteristics. They were given water but no feed for 12 hours to empty their gut. The fasted weight of the chickens was taken before they were humanely stunned using cervical dislocation technique (PIC, 2016; AVMA, 2020). Next, the carcasses were bled, scalded and de-feathered using hot water combined with manual plucking, followed by singeing with blue flame using gas burner. The shanks were then detached on the hock joints while the head and neck were also removed for dressed weight to be documented. The percent dressed weight was computed based on fasted weight. Evisceration was done by detaching the crop, gullet, trachea and preens glands. A straight cut was made at the back of the keel bone, while breast was slightly upturned and pressed frontward, revealing the viscera with the visceral organ that were detached totally by tugging. The lungs were separated from cautiously from the neck, heart, liver, kidneys and gizzard (giblet) and viscera. The gizzard was opened, its contents rinsed out and inner epithelial lining detached. The heart was made free from blood and adhering vessels. The eviscerated weight was recorded as the weight of carcass together with giblets. The interior organs, gastrointestinal tract and abdominal fat (fat deposited near the Bursa fabricius and the gizzard) were detached after evisceration.

Carcass was separated to individual parts. The parts and interior organs were weighed fresh using electronic scale and the weights converted to percentages of fasted weight. Carcass yield (without the feet, head and neck) breasts, drumsticks, thighs, and wings, abdominal fat, liver gizzard, kidney were separately weighted, and their percent ratio to the weight of the body at the slaughtering were determined. The carcass yield was evaluated as a function of the weight of the chicken at the slaughtering and the yield of the parts was evaluated as a function of the carcass weight.

\subsection{Data analysis}

The data collected on various parameters were subjected to One-Way ANOVA using the procedure of SPSS software. Significant treatment means were separated using the Duncan's Multiple Range Test and statistical differences declared at 5\% $(\mathrm{P}<0.05)$. Data were analyzed 
International Journal of Agriculture and Environmental Research

ISSN: 2455-6939

Volume: 07, Issue: 01 "January-February 2021"

using SPSS statistical analysis package. Significant treatment means were separated using Duncan Multiple Range Test equivalent in SPSS.

\section{RESULTS AND DISCUSSION}

Table 2: Performance of broiler chickens fed aidan with turmeric in diets

\begin{tabular}{|c|c|c|c|c|c|c|}
\hline \multirow[b]{2}{*}{ Parameters } & \multicolumn{6}{|c|}{ Treatment groups } \\
\hline & T1 & T2 & T3 & T4 & T5 & T6 \\
\hline Initial weight (g) & $48.40 \pm 0.02^{\mathrm{NS}}$ & $48.0 \pm 0.01^{\mathrm{NS}}$ & $48.30 \pm 0.00^{\mathrm{NS}}$ & $48.0 \pm 0.03^{\mathrm{NS}}$ & $48.30 \pm 0.02^{\mathrm{NS}}$ & $48.40 \pm 0.02^{\mathrm{NS}}$ \\
\hline Final weight (g) & $2456.11 \pm 42.11^{\mathrm{b}}$ & $2458.50 \pm 45.65^{b}$ & $2585.66 \pm 53.00^{\mathrm{ab}}$ & $2778.67 \pm 56.12^{\mathrm{a}}$ & $2460.90 \pm 43.55^{b}$ & $2365.55 \pm 30.12^{b}$ \\
\hline Weight gain (g) & $2407.71 \pm 27.00^{c}$ & $2410.50 \pm 29.01^{c}$ & $2537.36 \pm 23.33^{b}$ & $2730.67 \pm 28.10^{\mathrm{a}}$ & $2412.60 \pm 29.43^{c}$ & $2317.15 \pm 24.22^{\mathrm{d}}$ \\
\hline Feed intake (g) & $6979.55 \pm 65.23^{a}$ & $6902.20 \pm 60.76^{a}$ & $6846.50 \pm 62.88^{a}$ & $6366.30 \pm 64.69^{c}$ & $6789.93 \pm 60.08^{a}$ & $6548.28 \pm 65.01^{b}$ \\
\hline Feed conversion ratio & $2.90 \pm 0.03^{a}$ & $2.86 \pm 0.05^{\mathrm{a}}$ & $2.70 \pm 0.03^{b}$ & $2.33 \pm 0.13^{c}$ & $2.81 \pm 0.09^{a}$ & $2.83 \pm 0.03^{a}$ \\
\hline Mortality rate (\%) & $6.70 \pm 0.02^{\mathrm{NS}}$ & $6.00 \pm 0.00^{\mathrm{NS}}$ & $6.00 \pm 0.02^{\mathrm{NS}}$ & $5.50 \pm 0.00^{\mathrm{NS}}$ & $6.00 \pm 0.00^{\mathrm{NS}}$ & $6.00 \pm 0.01^{\mathrm{NS}}$ \\
\hline
\end{tabular}

Table 2 shows the performance of birds fed diets containing aidan and turmeric. T4 had the highest $(\mathrm{p}<0.05)$ final live weight $(2778.67 \pm 56.12 \mathrm{~g})$ and weight gain $(2730.67 \pm 28.10 \mathrm{~g})$ followed by $\mathrm{T} 3(2585.66 \pm 53.00 \mathrm{~g}$ and $2537.36 \pm 23.33 \mathrm{~g})$ while $\mathrm{T} 6(2365.55 \pm 30.12 \mathrm{~g}$ and $2317.15 \pm 24.22 \mathrm{~g})$ had the least values $(\mathrm{p}<0.05)$ for these two indices. However, the final live weight of T4 was not different $(p>0.05)$ from that of T3. All the final live weights and weight gains were higher than those reported for birds fed diets containing garlic, ginger and their combination (Karangiya et al., 2016). Differences could be due to duration of the studies as present study was 14 days longer. Nevertheless, that T4 recorded the highest final weight and weight gain implies that combining turmeric with aidan at $0.5 \%$ each could improve final live weight and weight gain of broiler chickens. Similarly, T4 $(6366.30 \pm 64.69 \mathrm{~g})$ consumed the least $(\mathrm{p}<0.05)$ feed, followed by T6 $(6548.28 \pm 65.01 \mathrm{~g})$ while T1, T2, T3 and T5 consumed the highest. T4 $(2.33 \pm 0.13)$ also had the least $(\mathrm{p}<0.05)$ feed conversion ratio, followed by $\mathrm{T} 3$ $(2.70 \pm 0.03)$ while T1, T2, T5 and T6 had the highest $(\mathrm{p}<0.05)$. Values for the two indices were within those reported elsewhere for broiler birds (Ali et al., 2014). Also, that T4 group had the least feed intake and feed conversion ratio values than others indicate that the birds were more efficient in converting their lower feed intake to meat. This agrees with reports that phytoadditives could increase feed efficiency of birds (Karaskova et al., 2015) and that additive effect is better felt when two or more spices are combined in diets. Mortality rate of the birds was not affected ( $p>0.05$ ) by inclusion of turmeric and aidan in feed, either alone or in combination. 
International Journal of Agriculture and Environmental Research

ISSN: 2455-6939

Volume: 07, Issue: 01 "January-February 2021"

Table 3: Economics of production of broiler chickens fed aidan with turmeric in diets

Treatment groups

\begin{tabular}{|c|c|c|c|c|c|c|}
\hline Parameters & T1 & T2 & T3 & T4 & T5 & T6 \\
\hline Cost of feed ( $\# / \mathrm{kg})$ & $94.98 \pm 3.11^{\mathrm{NS}}$ & $105.56 \pm 3.01^{\mathrm{NS}}$ & $115.90 \pm 2.90^{\mathrm{NS}}$ & $113.34 \pm 2.22^{\mathrm{NS}}$ & $110.77 \pm 3.01^{\mathrm{NS}}$ & $100.23 \pm 2.51^{\mathrm{NS}}$ \\
\hline Cost of feed consumed (\#) & $662.92 \pm 10.00^{c}$ & $728.60 \pm 12.56^{b}$ & $793.51 \pm 13.04^{a}$ & $721.56 \pm 12.57^{b}$ & $752.12 \pm 31.90^{\mathrm{ab}}$ & $656.33 \pm 11.11^{c}$ \\
\hline Feed cost/weight gain ( $(\sharp / \mathrm{kg})$ & $275.44 \pm 5.90^{\mathrm{b}}$ & $301.90 \pm 6.76^{a}$ & $312.93 \pm 7.00^{\mathrm{a}}$ & $264.08 \pm 5.99^{b}$ & $311.26 \pm 6.66^{a}$ & $283.65 \pm 5.98^{\mathrm{ab}}$ \\
\hline
\end{tabular}

a,b,cMeans in same row with different superscript are significantly different $(p<0.05) ;{ }^{\text {Ns }}$ Not significantly different $(P>0.05)$

Economics of producing broiler birds fed aidan and turmeric in diets is presented in Table 3. There was no significant difference $(\mathrm{p}>0.05)$ in the costs of the six experimental diets. Group T3 $(\$ 793.51 \pm 13.04)$ recorded the highest $(\mathrm{p}<0.05)$ cost of feed consumed, which was not different $(\mathrm{p}>0.05)$ from that of T5 $(\$ 752.12 \pm 31.90)$, while groups T1 ( $\$ 662.92 \pm 10.00)$ and T6 ( $\$ 656.33 \pm 11.11)$ had the least values $(\mathrm{p}<0.05)$. The cost of feed per weight gain $(\$ / \mathrm{kg})$ shows that the cost of weight gained by chickens fed T4 (264.08 \pm 5.99$)$ and T1 (275.44 \pm 5.90$)$ diets were the lowest $(p<0.05)$, though not different $(p>0.05)$ from that of T6 $(283.65 \pm 5.98)$. The values for cost of feed consumed were within the range reported for broiler chickens elsewhere (Odoemelam et al., 2013), but feed cost per weight gain values were higher in the present study. Differences could be due to the higher cost of the spices, especially aidan. Aidan was the most expensive spice and T3 had the highest aidan inclusion level of $1.0 \%$. The higher cost of aidan possibly increased the cost of feed consumed and the feed cost per weight gain for T3. This implies that to reap the benefit of aidan inclusion (enhanced weight gain), it may not be included at more than $0.5 \%$ in broiler chicken diets.

Table 4: Dressed-out parts and organs of broiler chickens fed aidan with turmeric in diets

\begin{tabular}{|c|c|c|c|c|c|c|}
\hline \multirow[b]{2}{*}{ Parameters (as \% of plucked weight) } & \multicolumn{6}{|c|}{ Treatment groups } \\
\hline & T1 & T2 & T3 & T4 & T5 & T6 \\
\hline Head & $1.93 \pm 0.01^{\mathrm{NS}}$ & $1.97 \pm 0.01^{\mathrm{NS}}$ & $2.33 \pm 0.00^{\mathrm{NS}}$ & $2.05 \pm 0.02^{\mathrm{NS}}$ & $1.98 \pm 0.00^{\mathrm{NS}}$ & $2.00 \pm 0.01^{\mathrm{NS}}$ \\
\hline Neck & $5.56 \pm 0.20^{\mathrm{NS}}$ & $5.60 \pm 0.26^{\mathrm{NS}}$ & $5.50 \pm 0.23^{\mathrm{NS}}$ & $5.00 \pm 0.30^{\mathrm{NS}}$ & $5.89 \pm 0.31^{\mathrm{NS}}$ & $5.65 \pm 0.34^{\mathrm{NS}}$ \\
\hline Shanks & $3.04 \pm 0.03^{\mathrm{NS}}$ & $3.21 \pm 0.03^{\mathrm{NS}}$ & $3.34 \pm 0.00^{\mathrm{NS}}$ & $3.12 \pm 0.01^{\mathrm{NS}}$ & $3.20 \pm 0.01^{\mathrm{NS}}$ & $3.20 \pm 0.04^{\mathrm{NS}}$ \\
\hline Liver & $2.45 \pm 0.00^{\mathrm{NS}}$ & $2.33 \pm 0.02^{\mathrm{NS}}$ & $2.70 \pm 0.01^{\mathrm{NS}}$ & $2.28 \pm 0.00^{\mathrm{NS}}$ & $2.80 \pm 0.03^{\mathrm{NS}}$ & $2.64 \pm 0.02^{\mathrm{NS}}$ \\
\hline Heart & $0.65 \pm 0.01^{\mathrm{NS}}$ & $0.67 \pm 0.02^{\mathrm{NS}}$ & $0.64 \pm 0.00^{\mathrm{NS}}$ & $0.66 \pm 0.01^{\mathrm{NS}}$ & $0.63 \pm 0.00^{\mathrm{NS}}$ & $0.67 \pm 0.01^{\mathrm{NS}}$ \\
\hline Pancreas & $0.26 \pm 0.01^{\mathrm{NS}}$ & $0.20 \pm 0.00^{\mathrm{NS}}$ & $0.22 \pm 0.00^{\mathrm{NS}}$ & $0.21 \pm 0.00^{\mathrm{NS}}$ & $0.22 \pm 0.00^{\mathrm{NS}}$ & $0.25 \pm 0.01^{\mathrm{NS}}$ \\
\hline
\end{tabular}


International Journal of Agriculture and Environmental Research

ISSN: 2455-6939

Volume: 07, Issue: 01 "January-February 2021"

$\begin{array}{lllllll}\text { Gizzard } & 2.15 \pm 0.03^{\mathrm{NS}} & 2.35 \pm 0.01^{\mathrm{NS}} & 2.33 \pm 0.02^{\mathrm{NS}} & 2.30 \pm 0.01^{\mathrm{NS}} & 2.22 \pm 0.02^{\mathrm{NS}} & 2.08 \pm 0.02^{\mathrm{NS}} \\ \text { Spleen } & 0.11 \pm 0.00^{\mathrm{NS}} & 0.13 \pm 0.00^{\mathrm{NS}} & 0.12 \pm 0.00^{\mathrm{NS}} & 0.24 \pm 0.00^{\mathrm{NS}} & 0.17 \pm 0.00^{\mathrm{NS}} & 0.16 \pm 0.00^{\mathrm{NS}} \\ \text { Intestine } & 4.98 \pm 0.00^{\mathrm{NS}} & 5.32 \pm 0.11^{\mathrm{NS}} & 4.99 \pm 0.12^{\mathrm{NS}} & 4.10 \pm 0.03^{\mathrm{NS}} & 4.91 \pm 0.19 & 5.50 \pm 0.20^{\mathrm{NS}} \\ \text { Abdominal fat } & 2.25 \pm 0.03^{\mathrm{a}} & 1.31 \pm 0.01^{\mathrm{b}} & 0.87 \pm 0.00^{\mathrm{b}} & 0.80 \pm 0.00 \mathrm{~b}^{\mathrm{b}} & 1.01 \pm 0.01^{\mathrm{b}} & 0.80 \pm 0.00^{\mathrm{b}}\end{array}$

a,bMeans in same row with different superscript are significantly different $(p<0.05)$; ${ }^{\text {NS}}$ Not significantly different $(P>0.05)$

Table 4 shows the dressed-out parts and organ weights as percentages of the plucked weight. Results indicate that the head, neck, shanks, liver, heart, pancreas, gizzard, spleen and intestines were not affected $(\mathrm{p}>0.05)$ by inclusion of aidan and or turmeric in the diets. There were significant differences $(\mathrm{p}<0.05)$ in the abdominal fat values. Groups T4 and T6 had the least $(\mathrm{p}<0.05)$ abdominal fat $(0.80 \pm 0.00 \%)$ while $\mathrm{T} 1(2.25 \pm 0.03 \%)$ had the largest value $(\mathrm{p}<0.05)$. These values are within range of values reported broiler chickens (Kana et al., 2017). However, the lower abdominal fat record for all the treatments except the control (T1) could be due to inclusion of the spices in the diets. This could be so because according to (Karaskova et al., 2015), inclusion of phyto-additives in broiler chicken diets could minimize fat deposition in the body of the birds as they be modifying fat metabolism pathway in the birds (Karaskova et al., 2015). Therefore, to achieve low fat in broilers, a quality desired by consumers in this era of healthy eating, may require the inclusion of spices in the diets of birds.

Table 5: Carcass characteristics of broiler chickens fed aidan with turmeric in diets

\begin{tabular}{|c|c|c|c|c|c|c|}
\hline \multirow[b]{2}{*}{ Parameters } & \multicolumn{6}{|c|}{ Treatment groups } \\
\hline & T1 & T2 & T3 & T4 & T5 & T6 \\
\hline Slaughter weight (g) & $2370.15 \pm 37.09^{c}$ & $2372.45 \pm 30.67^{c}$ & $2495.16 \pm 36.90^{b}$ & $2681.42 \pm 40.03^{a}$ & $2374.77 \pm 38.00^{c}$ & $2282.76 \pm 40.27^{c}$ \\
\hline Plucked weight (g) & $2291.94 \pm 30.78^{c}$ & $2296.53 \pm 29.00^{c}$ & $2415.31 \pm 32.11^{b}$ & $2595.61 \pm 31.30^{a}$ & $2298.78 \pm 38.26^{c}$ & $2209.71 \pm 34.56^{c}$ \\
\hline Dressed weight (g) & $1780.38 \pm 23.90^{b}$ & $1792.67 \pm 22.17^{b}$ & $1879.11 \pm 23.45^{\mathrm{ab}}$ & $2047.94 \pm 20.99^{a}$ & $1786.15 \pm 22.47^{b}$ & $1723.35 \pm 25.01^{b}$ \\
\hline Dressing \% & $77.68 \pm 6.77^{\mathrm{NS}}$ & $78.06 \pm 5.90^{\mathrm{NS}}$ & $77.80 \pm 6.01^{\mathrm{NS}}$ & $78.90 \pm 5.98^{\mathrm{NS}}$ & $77.70 \pm 6.90^{\mathrm{NS}}$ & $77.99 \pm 5.33^{\mathrm{NS}}$ \\
\hline \multicolumn{7}{|c|}{ Cut-up parts (as \% of plucked carcass) } \\
\hline Breast & $20.10 \pm 1.23^{b}$ & $20.05 \pm 1.89^{b}$ & $20.00 \pm 1.00^{\mathrm{b}}$ & $23.46 \pm 0.99^{a}$ & $20.51 \pm 1.88^{b}$ & $20.22 \pm 1.78^{b}$ \\
\hline Thighs & $15.34 \pm 0.91^{\mathrm{NS}}$ & $14.99 \pm 0.45^{\mathrm{NS}}$ & $15.00 \pm 0.29^{\mathrm{NS}}$ & $15.2 \pm 0.17^{\mathrm{NS}}$ & $15.30 \pm 0.62^{\mathrm{NS}}$ & $15.20 \pm 0.89^{\mathrm{NS}}$ \\
\hline Wings & $14.08 \pm 0.55^{\mathrm{NS}}$ & $14.73 \pm 0.68^{\mathrm{NS}}$ & $14.85 \pm 0.88^{\mathrm{NS}}$ & $14.08 \pm 0.90^{\mathrm{NS}}$ & $14.02 \pm 0.34^{\mathrm{NS}}$ & $14.00 \pm 0.67^{\mathrm{NS}}$ \\
\hline Drumsticks & $13.02 \pm 0.23^{\mathrm{NS}}$ & $13.01 \pm 0.65^{\mathrm{NS}}$ & $13.00 \pm 0.46^{\mathrm{NS}}$ & $13.00 \pm 0.45^{\mathrm{NS}}$ & $13.09 \pm 0.22^{\mathrm{NS}}$ & $12.97 \pm 0.12^{\mathrm{NS}}$ \\
\hline Back & $14.08 \pm 0.50^{\mathrm{NS}}$ & $14.13 \pm 0.78^{\mathrm{NS}}$ & $14.11 \pm 0.67^{\mathrm{NS}}$ & $13.50 \pm 0.77^{\mathrm{NS}}$ & $14.05 \pm 0.78^{\mathrm{NS}}$ & $14.66 \pm 0.22^{\mathrm{NS}}$ \\
\hline
\end{tabular}


International Journal of Agriculture and Environmental Research

ISSN: 2455-6939

Volume: 07, Issue: 01 "January-February 2021"

Table 5 shows the carcass characteristics of broiler chickens fed aidan with turmeric in diets. T4 had the highest $(\mathrm{p}<0.05)$ slaughter $(2681.42 \pm 40.03 \mathrm{~g})$ and plucked $(2595.61 \pm 31.30 \mathrm{~g})$ weights while T6 had the least slaughter $(2282.76 \pm 40.27 \mathrm{~g})$ and plucked $(2282.76 \pm 40.27 \mathrm{~g})$ weights. But, the least values were not different ( $>0.05$ ) from those for T1, T2 and T5.Similarly, T4 had the highest $(\mathrm{p}<0.05)$ dressed weight $(2047.94 \pm 20.99 \mathrm{~g})$, which was not different $(\mathrm{p}>0.05)$ from that of T3 $(1879.11 \pm 23.45 \mathrm{~g})$ while T6 $(1723.35 \pm 25.01 \mathrm{~g})$ had the least $(\mathrm{p}<0.05)$ dressed weight, which was not different ( $>0.05$ ) from values reported for T1, T2, T3 and T5.For the slaughter, plucked and dressed weights, group T4 had the highest values. This trend could have been influenced by the final live weight in which T4 value was still the highest.

T4 had the highest $(\mathrm{p}<0.05)$ percent breast weight $(23.46 \pm 0.99)$ while T3 $(20.00 \pm 1.00)$ was the least $(p<0.05)$. However, the least value was not different $(p>0.05)$ from that of $\mathrm{T} 1, \mathrm{~T} 2, \mathrm{~T} 5$ and T6. Chicken breast is the choicest part of broiler carcass besides drumsticks (Cevger et al., 2004). The breast is the site for most muscle deposition. Faster growth and deposition of muscle is one positive effect for adding feed additives to diets (Karaskova et al., 2015). Hence, the higher deposition of muscle in the breast, a desired part, could be attributed to co-inclusion of the aidan with turmeric. This implies that feeding broiler birds for better breast yield may benefit from addition of turmeric and aidan at $0.5 \%$ each to the diets. Finally, addition of aidan and turmeric, singly or in combination to diets of broiler chickens had no effect ( $p>0.05)$ on dressing percentage as well as thighs, wings, drumsticks and back of the carcasses.

\section{CONCLUSION}

The study examined the effect of co-including aidan and turmeric in diets on the performance, carcass and economics of production of broiler chickens. Co-including $0.5 \%$ of aidan with $0.5 \%$ of turmeric (T4) in diets of broiler chickens improved final live weight and weight gain as well as slaughter, plucked and dressed weights but decreased feed intake and feed conversion ratio. The carcass breast, a premium part of the carcass was also improved for birds consuming T4 diets. But, adding the spices alone or in combination suppressed abdominal fat deposition which is desirable for the current anti-fat meat culture. We conclude that $\mathrm{T} 4$ diet could be fed to broiler birds for optimal performance, carcass and bio-economic indices.

\section{REFERENCES}

1. Achi, O. K. (2006). Composition and antibacterial activities of Tetrapleura tetraptera Taub pod extracts. Research Journal of Microbiology, 1(5): 416 - 422. 
International Journal of Agriculture and Environmental Research

ISSN: 2455-6939

Volume: 07, Issue: 01 "January-February 2021"

2. Adeyemo, G. O. (2014). Effect of aqueous Tetrapleura tetraptera (African porridge fruit) on carcass characteristics and organ weights of broiler chickens. Nigerian Journal of Rural Extension and Development, 8: 75 - 78.

3. Aladesanmi, A. J. (2007). Tetrapleura tetraptera: molluscicidal activity and chemical constituents. African Journal of Traditional, Complementary and Alternative Medicines, 4 (1): 23-36.

4. AVMA (2020). AVMA Guidelines for the Euthanasia of Animals: 2020 Edition. American Veterinary Medical Association (AVMA). Schaumburg, Illinois, USA. Pp 121. https://www.avma.org/sites/default/files/2020-01/2020-Euthanasia-Final-1-1720.pdf

5. Bejar, E. (2018). Turmeric (Curcuma longa) root and rhizome and root and rhizome extracts. ABC-AHP-NCNPR Botanical Adulterants Prevention Programme. Botanical Adulterants Bulletin, May, p. 11.

6. Cevger, Y., Sariozkan, S. and Guler, H. (2004). The effect of the sale of whole or cut up chicken meat on enterprise income according to season. Turkish Journal of Veterinary and Animal Sciences, 28: 399-402.

7. EC (2005). Ban on antibiotics as growth promoters in animal feed enters into effect. $\begin{array}{llll}\text { European Commission } & \text { (EC) Pess }\end{array}$ https://ec.europa.eu/commission/presscorner/detail/en/IP_05_1687.

8. Fallah, R. and Mirzaei, E. (2016). Effect of dietary inclusion of turmeric and thyme powders on performance, blood parameters and immune system of broiler chickens. Journal of Livestock Science, 7:180-186.

9. Ingweye, J. N., Egbo, G. O. and Kalio, G. A.(2019). Influence of aidan and turmeric as additives on blood chemistry, proximate composition and organoleptic indices of broiler chickens. Journal of Agricultural Research and Development, 18: 90-106.

10. Ingweye, J. N., Okon, B. I., Ubua, J. A. and Essien, A. I. (2008). Performance of broiler chickens fed fish and shrimp wastes. Asian Journal of Animal Sciences, 2 (2): 58-63.

11. Jansen, C. (2020). Garlic shortage while ginger demand spikes. https://www.freshplaza.com/article/9208979/garlic-shortage-while-ginger-demandspikes/

12. Kana, J. R., Mube, K. H., Ngouana, T. R., Komguep, R., Yangoue, A., Tsafong, F. and Teguia, A. (2017). Growth performances and serum biochemical response of broiler 
International Journal of Agriculture and Environmental Research

ISSN: 2455-6939

Volume: 07, Issue: 01 "January-February 2021"

chickens fed on diet supplemented with Tetrapleura tetraptera fruit powder as substitute to antibiotic growth promoters. International Journal of Innovation and Applied Studies, 21(1): $68-76$.

13. Karangiya, V. K.,Savsani, H. H.,Patil, S. S., Garg, D. D., Murthy, K. S., Ribadiya, N. K., Vekariya, S. J. (2016). Effect of dietary supplementation of garlic, ginger and their combination on feed intake, growth performance and economics in commercial broilers. Veterinary World, 9 (3): 245-250.

14. Karaskova, K., Suchy, P. and Strakova, E. (2015). Current use of phytogenic feed additives in animal nutrition: a review. Czech Journal of Animal Sciences, 60(12): 521 530.

15. Khan, R. U., Naz, S., Javdani, M., Nikousefat, Z., Selvaggi, M., Tufarelli, V., Laudadio, V. (2012). The use of Turmeric (Curcuma longa) in poultry feed. World's Poultry Science Journal, 68: 97-103.

16. Mani, A. and Kabiraj, A. (2019). Export potential of spices and its value added products. Agriculture and Food: E-Newsletter, 1 (8): 338-347.

17. Nasri, H., Sahinfard, N., Rafieian, M., Rafieian, S., Shirzad, M., Rafieian-kopaei, M. (2014). Turmeric: a spice with multifunctional medicinal properties. Journal of HerbMed Pharmacology, 3 (1): 5-8.

18. Nweze, B. O., Nwankwegu, A. E. and Ekwe, O. O. (2011). The performance of the broiler chickens on African porridge fruit (Tetrapleura tetraptera) pod under different feeding regimes. Asian Journal of Poultry Science, 5(4): 144 - 149.

19. Olorunleke, S. O., Vilawa, G. and Ogeri, O. I. (2016). Comparative effect of aidan tree fruit, rosemary and thyme on the growth performance and carcass characteristics of broiler chickens. In: Proceedings of $21^{\text {st }}$ Annual Conference of Animal Science Association of Nigeria from September $18-22$ at Port Harcourt, Nigeria.

20. Oyegun, C. U. and Adeyemo, A. M. (1999). Port Harcourt Region. Department of Geography and Environmental Science, University of Port Harcourt, Publication Series Number One, Paragraphics, Port Harcourt, Nigeria.

21. PIC (2016). Practical Guidelines for On-farm Euthanasia of Poultry. Second ed. Puslinch, Ontario, Canada: Poultry Industry Council. https://www.poultryindustrycouncil.ca/wpcontent/uploads/2016/08/PIC-Practical-Guidelines-for-On-Farm-Euthanasia-ofPoultry.pdf. 
22. Puvaca, N., Stanacev, V; Glamocic, D., Levic, J.,Peric, L., Stanacev, V.,Milic, D. (2013). Beneficial effects of phyto-additives in broiler nutrition. World's Poultry Science Journal, 69: 27-34.

23. Sunil, D., Gupta, J. J. and Reddy, P. B. (2009). Effect of supplementation of ginger, garlic and turmeric in broiler chicken. The Indian Veterinary Journal, 86 (6): 644-645.

24. TPS (2019). New 2019 broiler performance objectives and nutrition specifications Aviagen. The Poultry Site. https://www.thepoultrysite.com/news/2019/05/new-2019broiler-performance-objectives-and-nutrition-specifications-aviagen.

25. USGAO (2011). Antibiotic Resistance: Agencies Have Made Little Progress Addressing Antibiotic Use in Animals. Report to the Ranking Member, Committee on Rules, House of Representatives, Washington DC, USA: US Government Accountability Office (USGAO). http://www.gao.gov/assets/330/323090.pdf.

26. Vyas, K. (2015). The cure is in the roots: turmeric. Journal of Nutritional Disorders and Therapy, 5 (3): 1-6.

27. Yadav, R. S. and Tarun, G. (2017). Versatility of turmeric: a review the golden spice of life. Journal of Pharmacognosy and Phytochemistry, 6 (1): 41-46. 